ON THE RELATION BETWEEN CHRONIC SINUSITIS AND CHRONIC COLD IN CHILDREN

By

Y. NAGOSHI, Z. KANEKO, K. TAKAMIZAWA AND

J. UMEZAWA

From the Department of Oto-Rhino-Laryngology, Toho University medical School.

(Director: Prof. Y. NAGOSHI)

Chronic sinusitis was observed in 6 patients (16.2\%) out of 37 patients suffering from chronic cold.

The incidence was similar to that obtained from the examination of the paranasal sinuses in children who were not suffered from chronic cold.

Any closed correlation between chronic sinusitis and chronic cold in children was not observil

\title{
小児慢性副鼻腔炎々 Anfälligkeit（感冒羅患傾向）との 関係についての検討
}

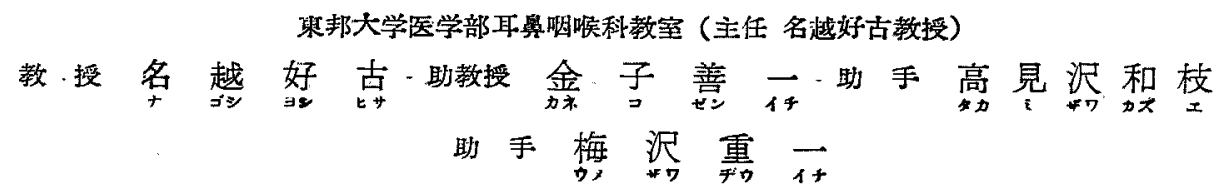

緒言

徉来より一般に風邪を引き易い子供は蓄膿症に雐り易 以，と考光られて扣り，文慢性副悬胵炎の発病原因の一 つとして，贋々繰返される鼻炎からの移行が挙げられて いる、しかし私達が、常，小况の副鼻腔炎害者を観察し ていると, 必すしもそれによつてのみ発来してくるもの とも限らないようである。

最近，繋邦大学小見科教室（主任久保政次教授）に路 いて, 感局罹患傾向罗の体質について詳細に研究してい るのでその協力によりこのような体質を有する小昌 の鼻膑，副鼻腔の状態を中心に詳細に検索し得たので， その成績を述へ，それについて検討を加えてみた。

小児の体貿の分類に関する報告は遠城寺氏をはじめ㮔 々あるが，小児の感冒眻患傾向を Nassau は Anfälligkeit と呼えで括り，これを4型に分類している。

1) 正常型 Normal typus

これは正常児の反応で、秋から冬にかけて 1 年に 1〜 2 回の感置に赝患するが9〜11 䪱には殆んど感冒にか $\checkmark ら な く な る も の$.

2) 連続感冒罹患傾向 Dauer anfälligkeit

これは感冒䍜患傾局が何時までも消失せず，常に小児 科医と耳鼻科医の間を往復しているようなるので，大体
3才から5〜6才の間，しよつちゆ5感染をおこし，経 過も永くか」るむので, シンパ性体質のものが多い.

3）早期感冒罹患傾向 Früh anfälligkeit 感冒䍜患傾向が乳児期に始まり学童期には消失してし， ま5すので，涔出性体質と関係むる症状を現わするのが 多以。

4）晚期感冒霍患傾向 Spät anfälligkeit

感冒䍜書傾向が減少する年令に特いて我か感染が相 次いで起るるので, 発育痛に関する訴えが多い。

\section{成綪および検討}

今回の詳細に観察し得た症例は37 例で、これらは小 呪科的に種々検索の結果 Anfälligkeit と診断されたも のである・この年令別にみた感冒篗患傾向は第 1 表の如 くで，1〜2才並びに 学童初期のむのが比較的多いよ5 である.これらの症例是小児科では主として全身的に， 耳悬科では主に 局所的に 検索し，これら忞総合比較し た.な和耳鼻科では鼻症状の急性期は避けて検查叒施行 した.

病歴は Anfälligkeitを中心に，体質、アレルギー性 症状等を詳細に聴取し，㕛小留科室に和いて次の如く 全般に亘つて臨床検查学施行した。即ち

甲状腺機能検查として 


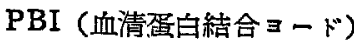

血清 総 Cholesterol

I'131 uptake

手根骨の化骨状態

○副腎皮質機能検查として

Thorn test (ACTH)

$17 \mathrm{OH}$ (17 KS)

○皮虔毛細管像

○血清電解質

$\mathrm{Ca}$, 無機燐 Alkali-

Phosphatase

$\mathrm{Cl}, \mathrm{Na}, \mathrm{K}$ (副腎皮筫㙨蒸)

O血清蛋白分展

○胸部レ線写真撮影

OScratch test

○その他，体重，身長，胸用の湘定

一般血液, 尿, 便検查, 結核反応検查

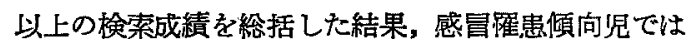
一般に甲状腺機能はある程度低下するすのが多く，又副 腎皮質機能の不全ぞきた場合が多く認められるようで ある・

耳鼻科においては，兽，耳，咽唉頭症状の聴取，鼻内所 見，鼻汁検查 (とくに細胞成分)，上顎洞穿刺，吸引及 洗涞 (可能の者のみ)，鼻腔，副鼻腔レ線撮影（造影成 使用又単純撮影，後前径および左右径の 2 方向)，後鼻 鏡検查，咽頭㭘查，耳鏡検查等，とくに副鼻腔を中心に 検索した．上下その 37 例の成績を総括して述べると， これら感冒罹患傾向の最初の発病時期は生後まもなくよ り満 1 才頃までの間に発現するものが大部分でする(25 (列).

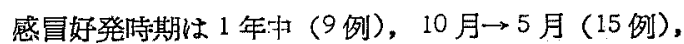
11 月 $\rightarrow 4$ 月 (10 例)，11月 $\rightarrow 6$ 月 (3例) で, 大半は秋 から春火かけて羅患する。

䍜患回数覀月 1 回 (25 例)，毎月 2 回 (7 例)，冬中 持続的 (2 例)，1 年师絶えまなく（3 例）で，秋から春 にかけて毎月 1〜2回罪患するとい5ものが多い

感胃雍患傾向を誘発してくる誘因と思われるすのは不 明のるのが大部分であるが (25例)，中心は肺炎 (4 例)， 麻疮 (2)，百日咳 (1)，敗血症 (1)，水痘 (1)，中耳炎 (1)，扇桃捅出後（1）などを経過した後に Anfälligkeit となつたと思われるるのがあつだ.

感冒罹患時の症状は発熱 (33 例, 89.2\%), 曼嗽 (27 例, $72.9 \%$ ), 多量の水様性鼻㴮 (13 例, 35.1\%)，鼻閉
塞 (15 例，40.5\%)，喘鳴（15 例，40.5\%) などが主で， その他噴䍛，頭痛，咽頭痛などがみられた。

既往歴で問題となるのは体質で，これらの症例は济出 性体诈，胸腺リンパ性体質あるいは神経閔節炎体質など

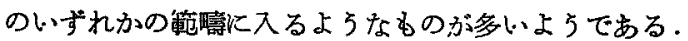

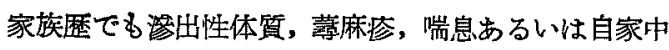
毒などの同様の体質䍜患傾向を認めるるのが多かつた。

泉症状の訴之（家族の者の訴方）では鼻漏（26例， $70.3 \%$ )，鼻閉塞 (15 例, 40.5\%)，後奥孔漏 (8例, 21.5 \%)などが多くみられた。

鼻肉所見は第 2 表 a)，b）の如くで，これらを総括す ると，高度の病変は少く，中等度病変と思われるすのが 5〜6例で，他つ大部分は著变を認めなかつた。

第 2 表 學灭所見
a) 學甲介の
b) 暴汁の性状 状態

\begin{tabular}{|c|c|}
\hline 正棠 & $22^{m}$ \\
\hline 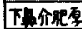 & 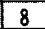 \\
\hline 中 190 & 2 \\
\hline 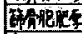 & 3 \\
\hline 9甲A期缩 & 2 \\
\hline 量 & 0 \\
\hline
\end{tabular}

\begin{tabular}{|c|c|c|c|}
\hline 7 & + & $\pi$ & $\mathrm{tt}$ \\
\hline Hisket & 3 & 2 & \\
\hline 棏決性 & 8 & 3 & 11 \\
\hline 精碓性 & 1 & 6 & 7 \\
\hline 服柱 & 2 & 1 & 3 \\
\hline \multicolumn{3}{|c|}{ 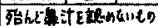 } & 11 \\
\hline
\end{tabular}

鼻汁検查として細胞成分の検索は好酸球の検出を目標 に詳しく調査し心が，第了表の如く，智外に Eosin 嗜 好細胞の出現率は少なかつた。

第 3 表 悬汁細胞成分 (24 例中)

\begin{tabular}{|c|c|c|c|c|c|c|c|}
\hline Ane & 0 & 0.1 & $2-3=$ & $4 \sim 5$ & $6 \sim 10=$ & $1-20$ & 2124 \\
\hline 世早中球 & 2 & 1 & 6 & 8 & 1 & 4 & 2 \\
\hline 好媪球 & 22 & 2 & 0 & 0 & 0 & 0 & 0 \\
\hline (9) & 18 & 4 & 2 & 0 & 0 & 0 & 0 \\
\hline 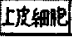 & 15 & 3 & 3 & 1 & 2 & 0 & 0 \\
\hline
\end{tabular}

副鼻腔のレ線所見を各症例の管骨洞，上顎洞の病变の 程度別に組合わせて総括してみると，第 4 表の如くで， このうち（土）までを活ら゙正常と見做と，はつきりと影 鼻腔に病変を認めたものは5〜6例であつた。

第 4 表 副畩腔レ線所見（27 例中）

\begin{tabular}{|c|c|c|c|c|c|c|c|}
\hline 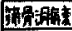 & - & \pm & \pm & + & + & $t$ & $\#$ \\
\hline 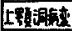 & - & - & \pm & \pm & + & $\#$ & $\pi$ \\
\hline 例数 & 11 & 1 & 7 & 2 & 1 & 1 & 4 \\
\hline
\end{tabular}

小児副离腔の 単純レ線撮影の判定は仲くさつがい が，病歷，奥内所見，洞穿刺洗浟，これにレ線所見など を総合すると，ほ心゙副鼻腔の状態は推定できる，ところ で，本症例中で上顎洞粘膜機能検査 $(20 \%$ Moljodol 使用）を施行し得た 7 例（第 5 表参绍）についてみる 
第 5 表上颚洞粘膜㙨能検沓觉施行した 正例 (7 例)

\begin{tabular}{|c|c|c|c|c|c|c|c|}
\hline \multirow{2}{*}{ 症 $($ 列 } & \multirow{2}{*}{ 年令 } & \multirow{2}{*}{\multicolumn{2}{|c|}{ 鼻内 所 }} & \multirow{2}{*}{ 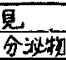 } & \multicolumn{2}{|c|}{ 儿線所自 } & \multirow{2}{*}{ 判定 } \\
\hline & & & & & 第骨洞 & 工影洞 & \\
\hline 新藤( & $9 \neq$ & - & - & - & - & - & 正 \\
\hline 新蒌(节) & 6 & $=$ & $=$ & 獎士 & - & - & 正 \\
\hline 裏田 & 6 & - & - & 粘 + & - & - & 正 \\
\hline 英田 & 9 & \pm & $=$ & 粘士 & \pm & $=$ & 正 \\
\hline 国京 & 7 & - & $\rightarrow$ & 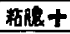 & + & $\#$ & + \\
\hline 勝本 & 5 & + & + & 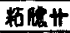 & $\pi$ & $H$ & + \\
\hline 金子 & 6 & + & + & 月1 & $\#$ & $\#$ & $\#$ \\
\hline
\end{tabular}

そ，大体病変の程度は推定でき，以上の関係を明らか炕 碐認し得たわけである.なおっ,このちち(第 5 表)の副鼻腔 に病变を認めた 3 症例についての諸検查の結果は, 他の 症例の体質的所見と比較して特別の差を認めなからた。

以上今回の検索した感冒篗患傾向の体質を有する小児 の症例 37 例の副酋腔の病变を中心総括すると第 6 表 の如くで, このうち(+) 以上を，はつきりとした病 第 6 表 副悬腔病変 (全造例)

変があると考えると, 全例 中 $16 \%$ 前後飞 副鼻胵见病 的所見を認めたことにな

\begin{tabular}{|c|c|c|c|}
\hline- & \pm & + & + \\
\hline 29 & 2 & 2 & 4 \\
\hline 31 19 $(83.8 \%)$ & \multicolumn{3}{|c|}{6 (例 $(16.2 \%)$} \\
\hline
\end{tabular}
了.

\section{考按}

小児科教室において感冒罪患傾向体質々 Allergy と の関係を重要視して，詳細な調查をなしたが，両者の間 に有意の関係はあまり著明ではなかつた，今回の検索に 扰いて Food allergens として, 卵白, 牛乳, 野菜等 の約 50 余種類 (Hollister-Stier Laboratory の pediatric Test Set を使用) の Scratch Test を試みた が，反店陽性は僅か 24 例中 3 例（ホーレン草，馬鈴諳， 綿の花粉の各 1 例）であり，之の他鼻汗，血液中の好酸 球の出見率，Thorn Test，血中の $\mathrm{Ca}, \mathrm{K}$ 量の測定等 を検索したが、これが Allergy との関保に括いて有意 の成續はあまり著明ではなかつた。

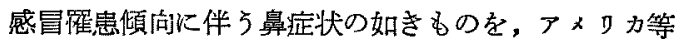
では allergic のるのという考学もつているよらであ るが, 私達の今回取扱つた症例では，その様な傾向は殆 んど認めなかつた。

次に小先慢性副鼻腔炎の発生頻或に関する報告は種々 西り，0.8\%から50\%まで報告者てより全く千差万別で あるが，副鼻腔を重点的に精查すれば相当の頻度に発顕 するすのと考完られ，最近で汢大体 30\% 前後の䍜患率 であると考觉られている・ところで今回の感冒淮患傾向 の調查成績では 37 例中 6 例 $(16.2 \%)$ 飞副鼻腔に 病变
を認めた。 又先に久保教授の報告した感冒䍜患傾向の成 續の中でも 36 例中 慢性副鼻腔炎の 頻度は 5 例 (14\%) であつた. 即らこれらの発生頻度は at randomに一般 小㫛の副鼻腔学猃察した場合の頻宾と少しも変らないわ けである.つまり感冒犀患傾向の体質であるから慢性副 鼻腔炎に罹り易い，ということは云兄ない，という結論 になる，風邪を引き易い子供は毎月 1〜2 回，あるいは しよちゆ5鼻炎を反復するが，これは必ずしる慢性副鼻 腔炎の発病原因とはなり得ないといらことで，この鼻炎 の反復は慢性副鼻腔炎とい5固定した慢性の炎症に移行 するものではなくて，これらはいずれる7〜8才以後に なると Anfälligkeit の消裙と共に自然に鼻症状子消失 してしま5一種の鼻粘膜の可逆性の反応ではなかららか と推論する。

副鼻腔炎の発生機転として従来より体質が取上げられ ているが，その体質の一部である感冒䍜患傾向は非常に 密接な関俰があるかの如く考完られるが，以上の成績か らでは，殆んど関保のないことを知り得た。

この事は私達が日常外来で経験する処で，いつも所謂 「青パナ」を沢山出しており，レ線像で高底の陰影があ つて，一見して高度の陰影があつて一見して高度の副鼻 腔炎汇罹患していると思われる子供でも，アレルキー性 疾患あるいは疾病篗患傾向を有しない煡康児童が多い場 合が多く、これに反して鼻内や副鼻腔レ線所見でもあま

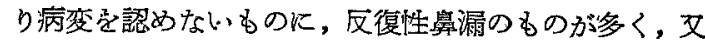
このようなものに上述の如き炎症霍患傾向の体質を有す るものが多く，これらは一般行気道の炎佂䍦患傾向体 質つ 1 分定としての鼻疾患であるかの如き感じをるける ものが眇くない事である.

\section{結語}

感冒罹患傾向見について，小胃科教堂において全身的

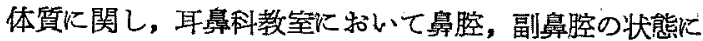
関して詳細な検索を行つた結果，感冒羅患傾向児 37 例 の副鼻腔の状態儿ついて，中等度の副鼻腔炎像を示した ものが5〜6例にすきず，他保軽度かおるいは殆えど变 化を認めていない，従って，感冒䍜患傾向が慢性副鼻腔 炎の原因として有力な証扰住認められなかつた。

要するに今回の成績では，感冒喔患傾向胃が，アレル ギー性であることも，慢性副鼻腔炎に陥り易い事も共に 肯定する結果は得られなかつた訳である。

\section{参考 文 献}

1) 久保, 稲葉, 前田: 治療, 39 焱, 4 号 (炤 32).

2）久保，穏葉：日本医事新報，No. 1519，(昭 28). 
3) Nassau: Z. Kinder-heilk. 57; 1 15, (1934).

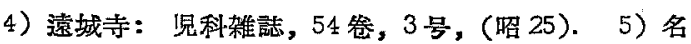

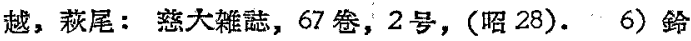

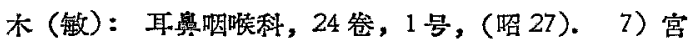
島：耳悬咽喉科，25 卷，9号，(昭 28). 8) 天沢: 躃床医学, 36 卷, 1 号, (昭 26).

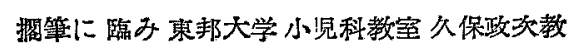
授，榣葉講師並びに同教室具各位の御嗳助に深 謝政します。

仯ま本稿の要旨は日本耳奥関東地方会第 347 回例会において報告した。

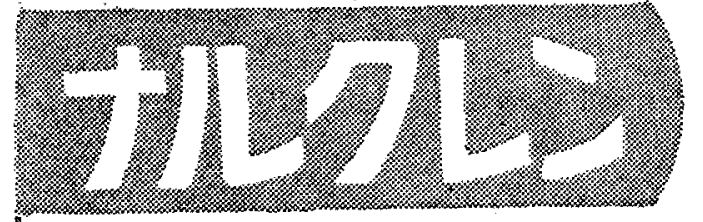

非引火性で食道刺戟が少なく，導入覚醒極めて 円滑。出血の增加は見ず唉頭反射が消失しない。 装置の取扱いは簢単で容易に麻酔を行えます。

【適応症】鼓膜切開. 穿刺. 耳節その他䁸腸切開. 中耳根手術. 錐体手術. アデノイド切除術. 術後有瘦処置.

\title{
NARCHLENE \\ トリフロールIチレン吸入麻醉藥

\author{
販 壳 元 \\ 株式会社 建 部 青 州 堂 アコマ医科工業株式会社 \\ 東京都交京区春木町 2 丁目東京都交京区本郷 1 丁目
}

製 造 元 日本アセチレン化学工業株式会社 